IZABELLA OLEJNICZAK ${ }^{1}$

STEFAN RUSSEL ${ }^{2}$

ANNA PRĘDECKA ${ }^{3}$

\title{
The impact of experimental forest fire on collembolan communities
}

Key words: Collembola, burnt plots, communities, forest

\section{Summary}

Our study was carried out in fresh pine mixed forest, Biala Forest, near

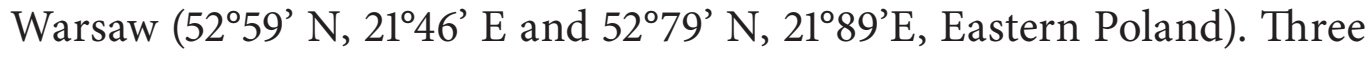
experimental plots, $1 \mathrm{~m}^{2}$ size, were chosen at random and burnt in June. Material was collected: just after experimental fire (in June ), 30, 60 and 90 days after fire (respectively: in July, August and September). On every sampling occasion 10 soil samples of an area of $10 \mathrm{~cm}^{2}$ and a depth of $5 \mathrm{~cm}$ were taken in each sampling plots: burnt plots, in border of burnt plots and in surroundings of burnt plots.

We found that experimental fire influenced on collembolan densities (Kruskall-Wallis test, $\mathrm{H}=8.29, \mathrm{P}=0.01$ ). Just after experimental fire we found no collembolans in burnt plots. In a period of 90 days following the experimental fire densities of springtails of burnt and surroundings were similar. Euedaphic springtails were the dominating group in burnt plots and contrary to the border of burnt plots and surroundings, we noticed no epigeic springtails. Contribution of epigeic, hemiedaphic and euedaphic species in collembolan communities of investigated areas could point to different defence strategies of these invertebrates. Immature individuals

1 Cardinal Stefan Wyszyński University, Institute of Ecology and Bioethics, Warsaw, e-mail:iza-olejniczak@wp.pl

2 Warsaw Agricultural University, Faculty of Agriculture and Biology, Department of Soil Environmental Science, Nowoursynowska Street 166, 02-787 Warsaw, Poland. 3 The Main School of Fire Service, Civil Safety Engineering Faculty, Department of Safety Analyses and Prognosis, Slowackiego Street 52/54, 01-629 Warsaw, Poland. 
of Collembola were the most numerous in burnt plots and at border of burnt plots and this phenomenon is probably crucial for reconstruction of collembolan communities after fire.

\section{Introduction}

Soil invertebrates, including microarthropods such as springtails (Collembola) may control soil processes and ecosystem function, (e.g. Seastedt 1984, Verhoef and Brussard 1990, Setälä and Huhta 1991, Bardgett and Chan 1999, Prescott 2000). Microarthropods occur in great number in forest soils, so they are the most important decomposers in forest ecosystems (Petersen and Luxton 1982).

The impact of fire on ecosystem functioning, especially on forest ecosystems became one of the crucial problems in ecology (Sgardelis and Margaris 1993, Driscoll 1999, Prescott 2000, Collett 2003, Minshall 2003).

The influence of fire on microarthropods is still controversial, because it depends on many factors such as: nature of fire (antropogenic or wild), fire intensity, fire frequency (Metz and Farrier 1973, Collet 2003, Dress and Boerner 2004). Although there are some studies, the knowledge about the influence of fire on forest microarthropods is still scarce (Dress and Boerner 2004).

The aim of presented study was to determine how the experimental fire may affect density and structure of collembolan communities.

\section{Methods}

Our study was carried out in fresh pine mixed forest, Biala Forest,

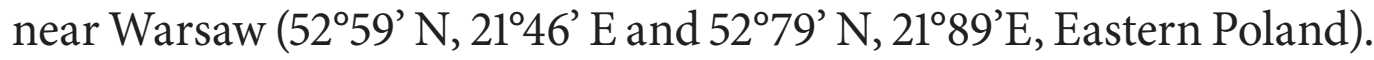
Podzol gley soil is dominating type of soil in Biala Forest.

During the study period the highest air and litter humidity were noted in June. The highest air temperature was noted in August, i.e. in the period of the lowest air and litter humidity. 
We burnt three, chosen at random plots in June 2005. The burnt plots were $1 \mathrm{~m}^{2}$ in size. The experimental fires lasted about $30 \mathrm{minu}-$ tes, up to total burnt-out of litter and herb layer. After burning we measured temperature at the ground and the mean temperature was $377^{\circ} \mathrm{C}$. The fire was put out using Protektol SAT-10 and Roteor M.

Material was collected just after controlled fire (in June) and 30, 60 and 90 days after burning, that means in July, August and September.

On every sampling occasion nine soil samples of an area of $10 \mathrm{~cm}^{2}$ and a depth of $5 \mathrm{~cm}$ were taken in each sampling plots. So we collected 36 samples in burnt plots (fire), 36 samples at the border of burnt plots (border) and 36 samples in the area, at a one metre from the burnt plots 36 (surroundings).

Springtails were extracted in Tullgren's apparatus and then the species of Collembola were determined basing on Stach's (1955), Fjellberg's $(1998,2007)$ keys and on taxonomic papers of Rusek (1982). Age of individuals was assessed upon their length.

Three groups of springtails' species were distinguished basing on their preferences to a soil layer: epigeon, hemiedaphon and euedaphon (Christiansen 1964).

For statistical analysis nonparametric Wilcoxon's test of rank differences for pairs and Kruskall-Wallis nonparametric analysis of variance were used, because the distribution of data was not normal, even after logarithm transformation.

Species diversity of collembolan communities was calculated with the Shannon-Wiener index using logarithms at a base of 2 . Hutcheson's (1970) test was used to check statistical significance of differences in the $\mathrm{H}^{\prime}$ index values.

\section{Results and discussion}

We found significant differences between densities of collembolan communities in burnt plots, at the border of burnt plots and in the surroundings of burnt plots (Tab. 1). Also time was the important factor that affected the abundance of springtail of investigated areas (Tab. 1). 
Table 1. Results of the ANOVA rank Kruskal-Wallis analysis of the impact of experimental fire ('place') and period following the burning ('time') on total numbers of springtails ('place' in analysis means data from burnt plots, border of burnt plots and surroundings; 'time' in analysis means data after burning and following days: 30,60 and 90 after fire)

\begin{tabular}{lccc}
\hline Sours of variation & Value of the statistic $\mathrm{H}$ & $\mathrm{df}$ & $\begin{array}{c}\text { Statistical } \\
\text { significance }\end{array}$ \\
\hline 'place' & 8.24 & 2 & $\mathrm{P}=0.01$ \\
'time' & 15.65 & 3 & $\mathrm{P}=0.001$ \\
\hline
\end{tabular}

Just after burning we found no collembolan in burnt plots and the highest densities of the springtails at the border of burnt plots (Fig.1). But 60 days following the fire densities of collembolan communities in burnt plots and at the border of burnt plots were similar. And after 90 days abundance of springtails was almost the same in all investigated places, i.e. in burnt plots, at the border of burnt plots and in surroundings (Fig.1).

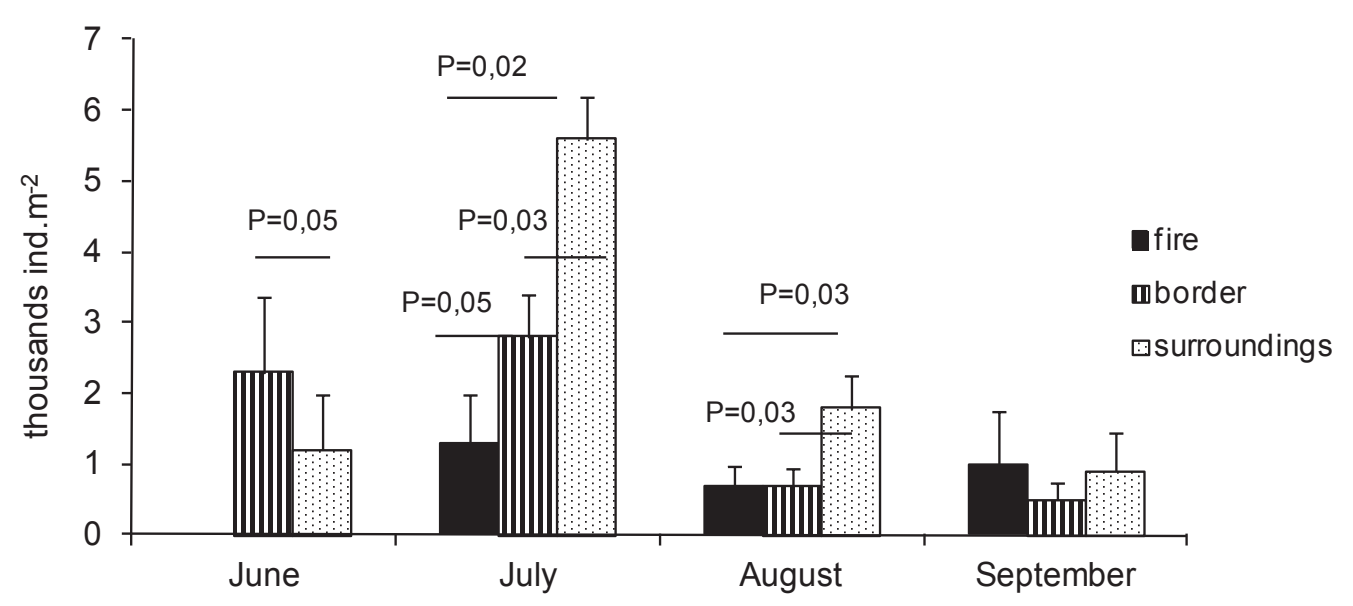

Fig. 1. Densities of collembolan communities in burnt plots (fire), at the border of burnt plots (border) and in the area at a distance of one metre from the burnt plots (surroundings) (Wilcoxon's test of rank, $\mathrm{P}$ value in one-way statistic test). 
Fourteen species of Collembola were distinguished in collected material (Tab. 2). Mesaphorura macrochaeta (43\% of total number of individuals) was the dominating species in collembolan communities of burnt plots (Tab. 2). At the border, such species as Entomobrya arborea and Parisotoma notabilis, were the most numerous (24\% of total number of individuals) (Tab. 2). Three species Cryptopygus bipunctatus, Mesaphorura macrochaeta and Pseudachorutella assigilata, were the most numerous in collembolan communities of surroundings of burnt plots (respectively: $20 \%, 18 \%$ and $16 \%$ of total number of individuals)

Table 2. Dominance structure (\% of the total number of individuals in 2005) among Collembola of different places (where: 'fire' means burnt plots, 'border' means the border of burnt plots and surroundings, surroundings means the area around the burnt plots).

\begin{tabular}{lccc}
\hline Species & Fire & Border & Surroundings \\
\hline Cryptopygus bipunctatus & 0 & 0 & 20 \\
Entomobrya arborea & 0 & 24 & 4 \\
Isotomiella minor & 0 & 4 & 10 \\
Isotomodes productus & 8 & 12 & 4 \\
Lepidocyrtus cyaneus & 0 & 0 & 6 \\
Lepidocyrtus lanuginosus & 25 & 12 & 6 \\
Mesaphorura macrochaeta & 43 & 12 & 18 \\
Neanura muscorum & 0 & 4 & 1 \\
Onychiurus armatus & 8 & 0 & 0 \\
Parisotoma notabilis & 0 & 24 & 0 \\
Proisotoma minuta & 8 & 0 & 0 \\
Pseudachorutella minuta & 8 & 0 & 6 \\
Schoetella ununguiculata & 0 & 8 & 8 \\
Stanophorura guadrispina & 8 & 0 & 1 \\
\hline
\end{tabular}

Species diversity of collembolan communities measured with the $\mathrm{H}^{\prime}$ index, for whole season, was the lowest $(\mathrm{P}<0.05)$ in the burnt plots (Tab. 3). We found no differences between diversity of collembolan communities of the border of burnt plots and surroundings (Table 3). 
Table 3. Diversity of collembolan communities (for whole season) measured as the Shannon-Wiener H' index of the burnt plot (fire), border of the burnt plot (border) and surroundings of the burnt plot (surroundings).

\begin{tabular}{lccc}
\hline & Fire & Border & Surroundings \\
\hline H'index value & 2.2 & 2.9 & 3.2 \\
\hline
\end{tabular}

Euedaphic collembolans were the dominating group of species in burnt plots and their contribution was clearly lower at the border of burnt plots (Fig. 2). Epigeic species were present only in collembolan communities at the border and the surroundings of burnt plots (Fig. 2).

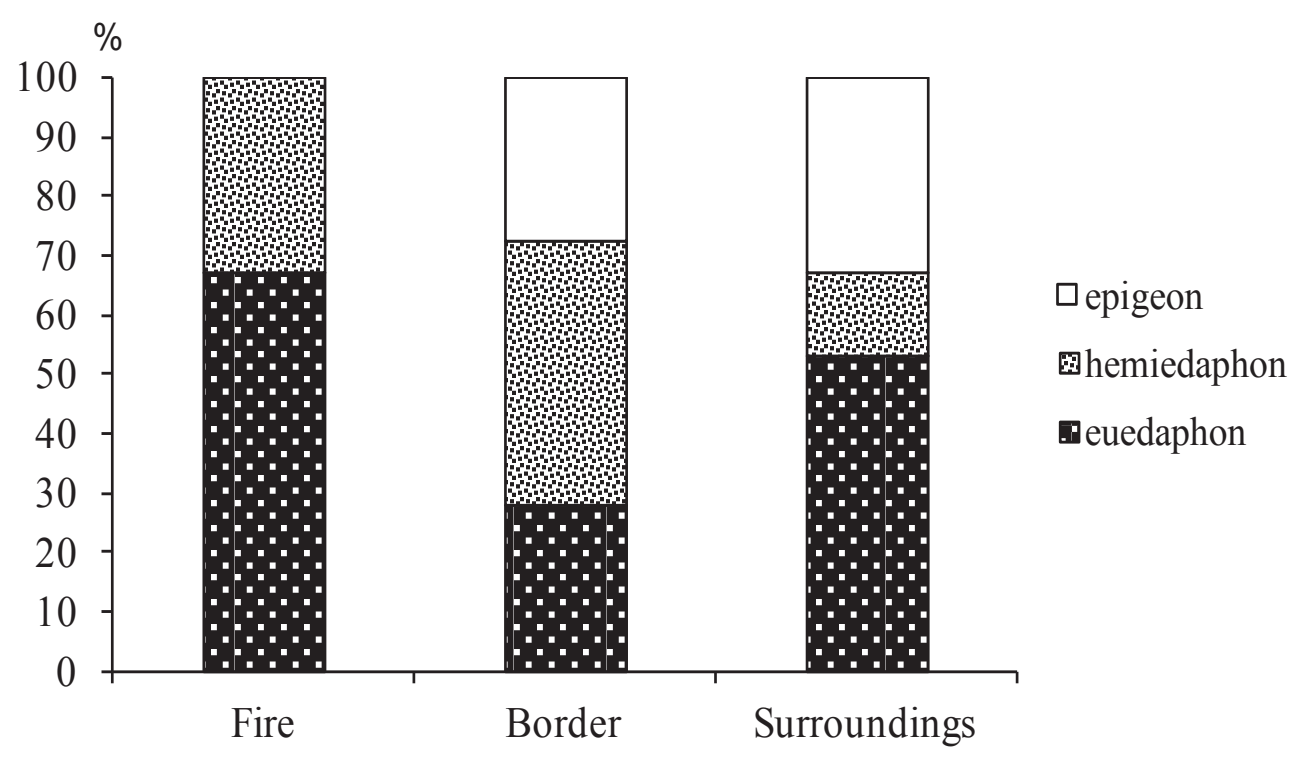

Fig. 2. Contribution (\% of total numbers of individuals) of ecological groups of Collembola in burnt plots (fire), at the border of burnt plots (border) and in the area around of burnt plots (surroundings).

Immature specimens were the most numerous among collembolans of burnt plots and border of burnt plots (Fig. 3). 


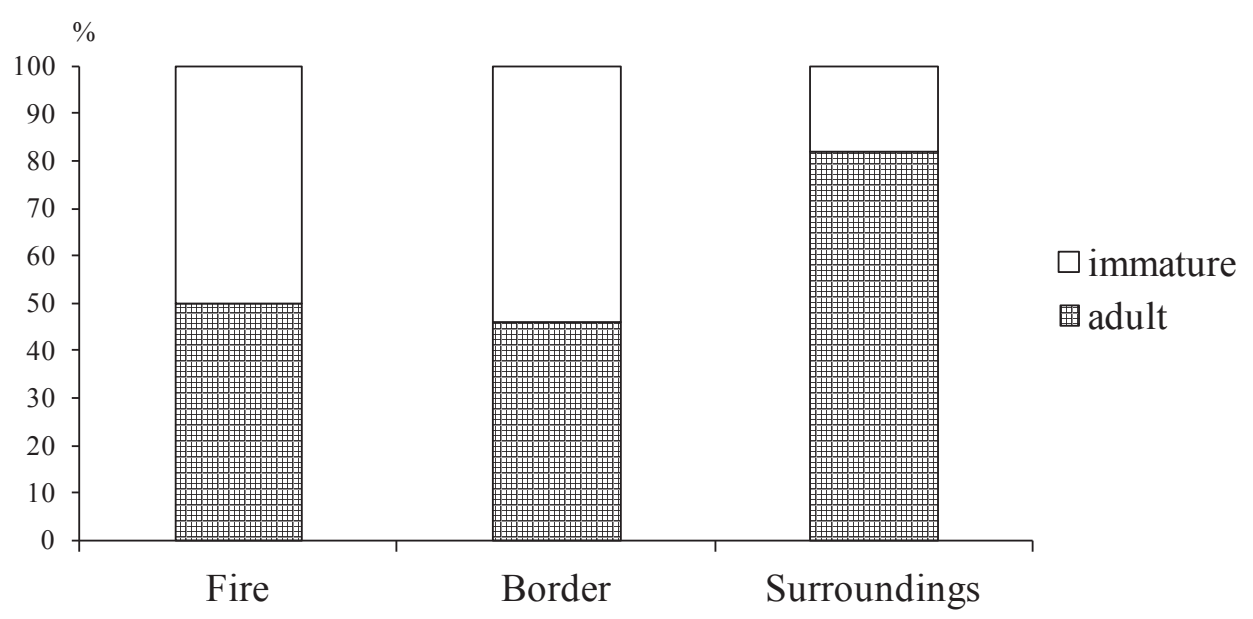

Fig. 3. Contribution (\% of total numbers of individuals) of immature and adult springtails of burnt plots (fire), border of burnt plots (border) and the area around of burnt plots (surroundings).

It is known that microarthropods are the most numerous at the upper soil layer and litter and their abundance decreases with a depth (Hale 1966). Wikars and Schimmel (2001) found that the fire affected the survival of invertebrates, especially that having thin cuticle. For example collembolans. So it is why many studies report reduced arthropod abundance immediately following the fire (e.g Sgardelis and Margaris 1993, Paquin and Coderre 1997, McCullough et al., 1998, Wikars and Schimmel 2001). In our study we also noticed severe reduced densities of springtails in burnt plots just after experimental fire, while we noticed the highest densities of collembolan communities at the border of the burnt plots following the fire. Abundance of Collembola was still lower in burnt than in surroundings after 60 days from the fire. This could be explain by environment condition, especially soil moister, food availability and diversity of the habitat that mainly affect the collembolan densities (Christiansen 1964, Huhta et al. 1967, Anderson 1978, Olejniczak $2000,2004,2007)$. Totally burnt of litter contributes the lack of food, optimal microclimates and microhabitats for collembolans (Sgardelis 
and Margaris 1993). But after 90 days collembolan densities in burnt plots did not differ from those of the borders and surroundings of burnt plots, what could be explained by colonisation processes. Vertical migration of Collembola due to climatic condition and food availability could be one of the possible explanation (Hale 1960, Lussenhope 1981), but other could be succession (Tokeshi 1993). In our study Mesaphorura macrochaeta, that belongs to euedaphic group, living in the soil, was the dominating species among Collembola in burnt plots. So euedaphic species could survive fire in deeper soil layers, because the highest temperatures are at the ground and they rapidly decrease with the depth of soil layer. Epigeic and, especially hemiedaphic species, living on the surface and/or in the litter, were characteristic for border of the burnt plots. Springtails that belong to these groups are able to cover long distances, even several centimetre per day (Ojala and Huhta 2001). Therefore, contribution of epigeic, hemiedaphic and euedaphic species in collembolan communities of investigated areas could point to different defence strategies of these invertebrates.

Furthermore some collembolans found in our experiment belong to pioneer species, for example Mesaphorura macrochaeta and Proisotoma minuta (Dunger 1991) and they were able to colonize rapidly burnt plots.

Fire affect not only densities of microarthropod communities but also their diversity (Haimi et al. 2000, Liiri et al. 2002). Wikars and Schimmel (2001) found that the fire reduced species richness. We also noticed the lowest species diversity of collembolan communities in burnt plots.

We found that collembolan communities of burnt plots are built manly by immature specimens. This could be explained by environmental preferences of young individuals of Collembola. They prefer deeper soil layers (Milne 1962). Thus immature individuals are able to avoid the fire. This is probably crucial for reconstruction of collembolan communities after the fire. 


\section{References}

Anderson J.M., 1978, Inter- and intra-habitat relationships between Woodland Cryptostigmata species diversity and the diversity of soil and litter habitats, Oecologia 32, 341-348.

Bardgett R. D., Chan K. F., 1999, Experimental evidence that soil fauna enhance nutrient mineralization and plant nutrient uptake in montane grassland ecosystems, Soil. Biol. Biochem. 31, 1007-1014.

Christiansen K., 1964, Bionomics of Collembola, Ann.Rev.of Entomol. 9, 147-178.

Collet N., 2003, Short and long-term effects of prescribed fires in autumn and spring on surface-active arthropods in dry sclerophyll eucalypt forests of Victoria, For. Ecol. Manage. 182, 117-138.

Dress W. J., Boerner R. E. J., 2004, Patterns of microarthropod abundance in oak-hickory forest ecosystems in relation to prescribed fire and landscape position, Pedobiologia 48, 1-8.

Driscoll K. G., Arocena J. M., Massicotte H. B., 1999, Post-fire soil nitrogen content and vegetation composition in Sub-Boreal spruce forests of British Columbia's central interior, Canada For. Ecol. Manage. 121, 227-237.

Dunger W., 1991, Zur Primärsukzession humiphager Tiergruppen auf Bergbauflächen, Zool.Jb. Syst. 118, 423-447.

Fjellberg A. 1998, The Collembola of Fennoscancandia and Denmark, Part I: Poduromorpha. Fauna Entomologica Acandinavica, vol. $35,1-184$

Fjellberg A., 2007, The Collembola of Fennoscancandia and Denmark, Part II: Entomobryomorpha and Symphypleon. Fauna Entomologica Acandinavica, vol. 42, 1-266.

Haimi J., Fritze H., Moilanen P., 2000, Responses of soil decomposer animals to wood-ash fertilization and burning in coniferous forest stand, For. Ecol. Manage. 129, 53-61.

Hale W.G., 1966, A population study of moorland Collembola, Pedobiologia 6, 65-99. 
Huhta V., Karppinen E., Nurminen M., Valpas A., 1967, Effects of silvicultural practices upon arthropod, annelid and nematode populations in coniferous soil, Ann. Zool. Fenn. 4, 87-135.

Hutcheson K., 1970, A test for comparing diversities based on the Shannon formula, J. Theor. Biol. 29, 151-154.

Liiri M., Haimi J., Setälä H., 2002, Community composition of soil microarthropods of acid forest soil as affected by wood ash application, Pedobiologia 46, 108-124.

Lussenhop J., 1981, Microbial and microarthropod detrital processing in a prairie soil, Ecology 62, 964-972.

McCullough D.G., Werner R.A., Neumann D., 1998, Fire and insects in northern boreal forest ecosystems of North America, Ann. Rev. Entomol. 43, 107-127.

Metz L.J., Farrier M.H., 1973, Prescribed burning and populations of soil mesofauna. Environ, Entomol. 2, 433-440.

Milne S., 1962, Phenology of natural population of soil Collembola, Pedobiologia 2, 41-52.

Minshall G.W., 2003, Responses of stream benthic macroinvertebrates to fire, For. Ecol. Manage. 178, 155-161.

Ojala R., Huhta V., 2001, Dispersal of microarthropods in forest soil, Pedobiologia 45, 443-450.

Olejniczak I., 2000, Effect of simplification of grass cultures and soil conditions on Collembola (Apterygota) communities in a lysimetric experiment, Pol. J. Ecol. 48, 209-224.

Olejniczak I., 2004, Communities of soil microarthropods with special reference to Collembola in midfield shelterbelts, Pol. J. Ecol. 52: $123-133$

Olejniczak I., 2007, Soil mesofauna (partialy Collembola) along transects: shelterbelts of different age and adjacent fields, Pol. J. Ecol., 55: 637-646.

Paquin, P., Coderre D., 1997, Deforestation and fire impact on edaphic insect larvae and other macroarthropods, Environ. Entomol. 26, 21-30.

Petersen H., Luxton M., 1982, A comparative analysis of processes, Oikos 39, 287-388. 
Prescott C. E., Maynard D. G., Laiho R., 2000, Humus in northern forests: friend or foe?, For. Ecol. Manage. 133, 23-36.

Rusek J., 1982, European Mesaphorura species of the sylvatica-group (Collembola, Onychiuridae, Tullbergiine), Acta ent. Bohemoslow 79, 14-30.

Seastedt T.R., 1984, The role of microarthropods in decomposition and mineralization processes, Ann. Rev. Entomol. 29, 25- 46.

Setälä H., Huhta V., 1991, Soil fauna increase Betula pendula growth: laboratory experiments with coniferous forest floor, Ecology 72, 665-671.

Sgardelis S.P., Margaris N.S., 1993, Effects of fire on soil micrarthropods of a phryganic ecosystem, Pedobiologia 37, 83-94.

Shannon C.E., Wiener W., 1963, The mathematical theory of communication, Univ. of Illinois Press, Urbana.

Stach J., 1955, Klucze do oznaczania owadów Polski, Cz.II, SkoczogonkiCollembola [Guide of insects of Poland. Part II, Springtails Collembola ] PWN, Warszawa

Verhoef H.A., Brussaard L., 1990, Decomposition and nitrogen mineralization in natural and agroecosystems: the contribution of soil animals, Biogeochemistry 11, 175-211.

Wikars L.O., Schimmel J., 2001, Immediate effects of fire-severity on soil invertebrates in cut and uncut pine forests, For. Ecol. Manage. 141, 189-200. 